\title{
EVALUASI STANDAR PELAYANAN MINIMAL PENGENDALIAN DIABETES MELITUS DI PUSKESMAS BOGOR UTARA KOTA BOGOR TAHUN 2019
}

\author{
Laila Rahmah $^{1)}$ dan Siti Khodijah Parinduri ${ }^{2)}$
}

\footnotetext{
${ }^{1)}$ Konsentrasi Manajemen Pelayanan Kesehatan, Fakultas Ilmu Kesehatan, Universitas Ibn Khaldun Bogor, Jl.KH. Sholeh Iskandar KM2 Kedung Badak Tanah Sareal Bogor 16162, Email: laila.sweet03@gmail.com

${ }^{2)}$ Fakultas Ilmu Kesehatan, Universitas Ibn Khaldun Bogor, Jl.KH. Sholeh Iskandar KM2 Kedung Badak Tanah Sareal Bogor 16162, Email: siti.parinduri@uika-bogor.ac.id
}

\begin{abstract}
Abstrak
Standar Pelayanan Minimal (SPM) pengendalian Diabetes Melitus adalah SPM yang harus dilaksanakan sesuai standar oleh Puskesmas. Menurut laporan kegiatan pengendalian diabetes melitus pada tahun 2018 terdapat 207 penderita Diabetes Melitus di wilayah kerja Puskesmas Bogor Utara dan belum semua penderita diabetes melitus mendapatkan pelayanan sesuai standar yang di tetapkan oleh Permenkes. Tujuan penelitian ini adalah untuk mengetahui evaluasi standar pelayanan minimal pengendalian diabetes melitus di Puskesmas Bogor Utara mulai dari Input, Proses dan Outputnya. Penelitian ini merupakan jenis penelitian kualitatif, dengan jumlah populasi yaitu 235 dan sampel berjumlah 10 orang yang dipilih berdasarkan. metode purposive sampling yaitu teknik sampling non random sampling Instrumen yang digunakan adalah pedoman wawancara, daftar ceklist observasi dan daftar ceklist telaah dokumen. Hasil penelitian menunjukan bahwa sumber daya manusia yang berkaitan dengan pengendalian diabetes melitus belum mencukupi, peralatan HbA1C yang belum memadai untuk melakukan pemeriksaan, ketersediaan obat insulin yang belum ada di Puskesmas serta pencapaian kinerja yang belum optimal Kesimpulan dari penelitian adalah pelaksanaan kegiatan pengendalian diabetes melitus di Puskesmas Bogor Utara belum dilaksanakan secara optimal yaitu belum semua penderita diabetes mendapatkan pemeriksaan $\mathrm{HbA} 1 \mathrm{C}$, serta tenaga sumber daya manusia belum mencukupi, hal ini mengakibatkan pencapaian kinerja yang masih rendah. Semoga dengan adanya penelitian ini Puskesmas Bogor Utara dapat mengevalusi dan menaggulangi hambatan-hambatan yang ada saat ini sehingga pengendalian diabetes melitus bisa dilaksanakan secara optimal.
\end{abstract}

\section{Kata Kunci: Evaluasi, SPM dan DM}

\section{Pendahuluan}

Standar Pelayanan Minimal (SPM) merupakan ketentuan mengenai jenis dan mutu pelayanan dasar yang merupakan urusan pemerintah wajib yang berhak diperoleh setiap warga negara secara minimal. SPM merupakan hal minimal harus dilaksanakan oleh Pemda untuk rakyatnya, maka target
SPM harus $100 \%$ setiap tahunnya (Permenkes No 43 tahun 2016 tentang SPM Bidang Kesehatan).

Pada Permenkes No 43 Tahun 2016 Tentang SPM Bidang Kesehatan berisi berbagai jenis pelayanan kesehatan untuk memenuhi kebutuhan kesehatan bagi setiap 
warga negara. Salah satunya terdapat jenis pelayanan Kesehatan Diabetes Melitus mendapatkan pelayanan Kesehatan sesuai standar. Pemerintah Kabupaten/Kota mempunyai kewajiban untuk memberikan pelayanan Kesehatan sesuai standar kepada seluruh penyandang diabetes melitus sebagai upaya pencegahan sekunder di wilayah kerjanya.

Menurut World Health Organization (WHO), Diabetes Melitus (DM) merupakan penyakit atau gangguan metabolisme kronis dengan multi etiologi yang ditandai dengan tingginya kadar gula darah disertai dengan gangguan metabolisme karbohidrat, lipid dan protein sebagai akibat dari insulfisiensi fungsi insulin, yang dapat disebabkan oleh gangguan produksi insulin oleh sel-sel beta langerhans kelenjar pankreas atau disebabkan oleh kurang responsifnya sel-sel tubuh terhadap insulin. Berdasarkan Perkumpulan Endokrinologi Indonesia (PERKENI, 2015) Diabetes Melitus (DM) merupakan suatu kelompok penyakit metabolic dengan karakteristik hiperglikemia yang terjadi karena kelainan sekresi insulin, kerja insulin atau kedua-duanya.

Saat ini di negara berkembang telah terjadi pergeseran penyebab kematian utama, dari penyakit menular ke penyakit tidak menular, dari penyakit infeksi ke penyakit degeneratif. Kecenderungan ini dipengaruhi oleh adanya dari perubahan gaya hidup tradisional ke gaya hidup modern, peningkatan prevalensi obesitas, kegiatan fisik berkurang yang menyebabkan gangguan sekresi insulin atau resistensi insulin sehingga insulin menjadi tidak efektif untuk menstimulasi pengambilan glukosa oleh jaringan (Ernawati, 2013). Sebagai salah satu PTM Diabetes Melitus menduduki peringkat ke-6 sebagai penyebab kematian. Sekitar 1,3 juta orang meninggal akibat diabetes dan $4 \%$ meninggal sebelum usia 70 tahun (Nordisk, 2013).

Menurut World Health Organization (WHO, 2016), Pada tahun 2015 jumlah penderita DM di dunia sebanyak 415 juta jiwa dan akan meningkat menjadi 642 juta jiwa di tahun 2040. Pada tahun yang sama juga ditemukan fakta bahwa dari 11 orang dewasa di dunia menderita diabetes melitus dan setiap 6 detik satu orang meninggal karena diabetes melitus (DM) Internasional Diabetes Federetion (IDF, 2015).

Menurut data World Health Organization (WHO, 2016) pada tahun 2014 di Asia Tenggara jumlah penderita diabetes melitus mencapai 96 juta orang dewasa dengan diabetes di 11 negara anggota di wilayah regional Asia Tenggara. Prevalensi diabetes diantara orang dewasa di wilayah regional Asia Tenggara meningkat dari 4,1\% pada tahun 1980 menjadi 8,6\% di tahun 2014 . Lebih dari $60 \%$ laki-laki dan $40 \%$ perempuan dengan diabetes meninggal sebelum berusia 70 tahun di wilayah regional Asia Tenggara. Populasi dari wilayah regional Asia Tenggara secara genetik memang rentan terhadap factor lingkungan sehingga memiliki ambang lebih rendah terhadap factor resiko seperti usia, kelebihan berat badan dan distribusi lemak tubuh. Diabetes terjadi 10 tahun lebih cepat di wilayah regional Asia Tenggara dari pada orang-orang di wilayah Eropa pada usia produktif.

Pada tahun 2015 Indonesia menempati peringkat ke tujuh dunia untuk prevalensi penderita diabetes tertinggi di dunia bersama dengan Cina, India, Amerika Srikat, Brazil, Rusia dan Meksiko dengan jumlah estimasi orang dengan diabetes sebesar 10 juta Internasional Diabetes Federetion (IDF Atlas 2015). Diabetes komplikasi merupakan penyebab kematian tertinggi ketiga di Indonesia (SRS, 2014). Prevalensi orang dengan diabetes di Indonesia manunjukkan 
kecenderungan meningkat yaitu dari $6,9 \%$ (2013) menjadi 8,5\% di tahun 2018, sehingga estimasi jumlah penderita di Indonesia mencapai lebih dari 16 juta (depkes, 2018).

Menurut profil kesehatan Kota Bogor tahun 2017 angka kecepatan kejadian DM mencapai 27.000 orang pertahun. Menurut data Puskesmas Bogor Utara dari tahun ketahun terjadi peningkatan jumlah penderita diabetes melitus. Pada tahun 2016 tercatat 134 penderita, pada tahun 2017 tercatat 148 penderita dan pada tahun 2018 tercatat 207

\section{Metode Penelitian}

Penelitian ini dilakukan di Puskesmas Bogor Utara Kota Bogor pada bulan Februari - Maret 2019. Jenis penelitian ini merupakan penelitian yang bersifat deskriptif melalui pendekatan kualitatif yang di dapatkan dengan metode Observasi, wawancara mendalam, dan telaah dokumen. Teknik pengumpulan data meliputi data primer melalui wawancara mendalam dan sekunder melalui dokumen-dokumen. Informan penelitian terdiri dari 10 orang yaitu Kepala Puskesmas, 1 Koordinator PTM, 1 orang dokter PTM, 1 orang Kepala Tata Usaha, 3 orang penderita DM dan 3 orang Non

\section{Hasil Penelitian}

\section{1) Input}

Input yang dilakukan pada penelitian ini meliputi 4 komponen antara lain yaitu SDM, pembiayaan, sarana dan prasarana serta kebijakan yang digunakan untuk melaksanakan standar pelayanan minimal pengendalian diabetes melitus di Puskesmas Bogor Utara Kota Bogor Tahun 2019.

\section{Sumber Daya Manusia}

Berdasarkan hasil observasi dan wawancaramendalam dengan Koordinator penyakit tidak menular (PTM) dan Kepala subbagian Tata Usaha Puskesmas bahwa penderita dari 4 kelurahan. Pada tahun 2018 bisa dikatakan jumlah penderita Diabetes Melitus di Puskesmas Bogor Utara yaitu 3,08\% dengan proporsi 101 laki-laki dan 106 pada perempuan. Di kelurahan Cibuluh 27 laki-laki dan 16 perempuan, di kelurahan Cimahpar 32 laki-laki dan 29 perempuan, di kelurahan Tanah Baru 42 laki-laki dan 61 perempuan dan $13,24 \%$ pasien menderita Obesitas di Puskesmas Bogor Utara yang merupakan salah satu faktor beresiko terkena diabetes melitus.

penderita DM. Berdasarkan topik penelitian dimana peneliti focus untuk melihat pengendalian Diabetes Melitus di puskesmas yaitu dengan faktor input yang terdiri dari Sumber Daya Manusia, Sarana dan Prasaran, Pembiayaan dan Kebijakan. Faktor proses yang terdiri dari . Pendataan penderita DM, Skrining faktor risiko DM, Melakukan edukasi, Melakukan rujukan ke FKRTL, Pelatihan teknis tentang DM, Penyediaan peralatan, Penyediaan obat DM, Pencatatan dan pelaporan, Monitoring dan evaluasi. Angka pencapaian kinerja di Puskesmas Bogor Utara Kota Bogor 2019.

jumlah petugas yang menangani Penyakit Tidak Menular (PTM) yaitu berjumlah 2 petugas yaitu dokter PTM sebagai penanganan bidang kuratif dan promotif dan perawat PTM sebagai penanganan preventif serta promotif. Berikut adalah kutipan hasil wawancara mendalam.

"seperti diagnosa ada penyakit DM dokter yang berhak mengeluarkan Petugasnya? Kalo petugasnya dokter PTM sama, penanggung jawab program PTM, jadi 2. '(Informan 12) 
"ada 2 ya kalo untuk dokter itu euuh..biasanya nanti dalam segi kurataifnya pengobatan resep pengobatan. Sedangkan tugas dari kedua-duanya perawat dan dokternya adalah dari segi euuhh..segi satu lagi apa namanya (berfikir) promotif jadi untuk menekan atau euuh..baik menekan ataupun untuk mengobati penyakit PTM." (Informan 14)

\section{Pembiayaan}

Pembiayaan atau anggaran untuk pelaksanaan pengendalian diabetes melitus di Puskesmas Bogor Utara bersumber dari dana Bantuan Oprasional Kesehatan (BOK) dan dari Badan Penyelenggara Jaminan Sosial (BPJS). Berikut Kutipan hasil wawancara mendalam dengan Kepala Puskesmas dan Kordinator Penyakit Tidak Menular.

"Ada BOK. Bantuan Operasional Kesehatan kemudian ada JKN." (Informan 11)

"Kalo,, kita kalo stik gula dari BPJS, eee,, kalo transport petugas dari BOK untuk ke posbindunya itu." (Informan 12)

3. Sarana dan Prasarana

Seluruh informan mengatakan bahwa ketersediaan sarana dan prasarana yang ada di Puskesmas sudah cukup memadai. Hal tersebut seperti yang diungkapkan sebagai berikut:

"sarana prasarana yang ada di puskesmas ya memang (mendeham), euuhh...bisa dibilang adalah standar yang ada di puskesmas dan yang ada di bogor utara itu untuk pengendalian pengobatan penyakit PTM khususnya diabetes melitus umumnya sudah cukup ya ada tersedia gitu yaa..dari mungkin untuk pemeriksaannya, labnya kita ada untuk gulanya dan untuk obatnya sudah tersedia sesuai peraturan dari Kemenkes ada di Puskesmas." (Informan 14)

"udah bagus ya, ada gitu pemeriksaan buat gula memang kalo yang $N$ itu blm ada di puskesmas, bagus yah udah bagus." (Informan 51)

\section{Kebijakan}

Kebijakan yang mengatur mengenai pengendalian diabetes melitus sudah ada yaitu terdapat pada pedoman surveilans diabetes melitus selain itu juga sudah berpedoman pada Instruksi Presiden no 1 tahun 2017 mengenai Gerakan Masyarakat Hidup Sehat (GERMAS). Berikut adalah kutipan hasil wawancara.

“ada." (Informan 11)

"Pada buku pedoman surveilans diabetes melitus .” (Informan 12)

"untuk pedoman pengendaliannya ada ya kita mengacu kepada Peraturan Mentri Kesehatan itu, kemudian juga euuh,,khususnya tentang penyakit yang tidak menular yah ada permenkes ya sedang ngetren-ngetrennya sekarang salah satunya juga untuk menekan penyakit tidak menular tersebut yaitu tentang Gerakan Masyarakat Sehat (GERMAS) salah satunya." (Informan 14)

\section{2) Proses}

Proses yang dilakukan pada penelitian ini tentang langkah- langkah kegiatan untuk melaksanakan standar pelayanan minimal 
pengendalian diabetes melitus di Puskesmas Bogor Utara tahun 2019 yang meliputi pendataan, skrinning factor risiko, edukasi, rujukan, pelatihan, peralatan, obat, pencatatan dan pelaporan serta monitoring dan evaluasi. Pada komponen proses peneliti melakukan observasi, telaah doukmen dan wawancara mendalam.

1. Pendataan Penderita Diabetes Melitus Pendataan yang dilakukan yaitu melalui anamnesa dan hasil laboratorium, Berikut hasil kutipan wawancara.

"Data lab, sama anamnesanya." (Informan 12)

"data euu..hasil pemeriksaan laboratorium ya, data alamat euи..nama, euu..berat badan paling kaya gitu aja ya." (Informan 13)

\section{Skrinning Faktor Risiko Diabetes} Melitus

Dalam proses skrining faktor risiko petugas melakukannya dengan cara mengukur tinngi badan, berat badan, lingkar perut untuk mengetahui indeks masa tubuhnya (IMT) kegemukan atau tidak serta menilai gejalagejala yang dikeluhkan oleh pasien.

"Ee,, sama seperti,,, deteksi yang lainnya, jadi eee screeningnya yang di BP umum juga, eee,, dari anamnesa awal ya, em sama dari, di posbindu juga di skrining, kita ada posbindu PTM." (Informan 12).

"Ee,ya dari anamnesanya dulu, nanti kalo anamnesa ya ditanya dulu emm keluhan dia apa, emm berat badannya menurun atau ngga, sering cepet lelah apa ngga, ada luka apa ngga, dari anamnesa ya, tetep dari anamnesa awalnya." (Informan 13)

\section{Melakukan Edukasi}

Dalam melakukan edukasi kepada penderita diabetes melitus Puskesmams Bogor Utara menyampaikan beberapa hal yaitu mengenai pola makan, aktifitas fisik seperti olahraga, terapi farmakologi dan membuat programprogram yang diantaranya adalah senam prolanis, kegiatan posbindu yang secara rutin dilakukan.

"Edukasinya ya biasa, sama se,,biasa aja sih untuk penderita diabetes yah, eee jaga pola makannya, eee dietnya, terus sama terapinya juga, ada olahraganya juga, eee sama kaya gitu. Kontrol teratur." (Informan 12)

"ya tadi pola makan yang harus dirubah yah, mengurangin yang gulagula terus olahraga teratur euhh..sama diet, diet itu aja diet makan"(Informan 53)

"Emm..sejauh ini sih saya belum pernah ya mendapatkan edukasi tentang diabetes melitus karna saya juga kan kurang update mengenai informasi di puskesmas" (Informan 111)

"Ada, prolanis namanya. Program Pengelolaan Penyakit Kronis" (Informan 11)

4. Melakukan Rujukan ke FKRTL

Rujukan yang diberikan Puskesmas Bogor Utara kepada penderita diabetes melitus yaitu berdasarkan adanya indikasi komplikasi penyakit lain dan penderita yang membutuhkan terapi obat insulin. Berikut kutipan wawancara:

"ee..itu biasanya emm..buat pasien yang memerlukan suntik insulin ya 
emm..atau еии..itu terindikasi adanya komplikasi penyakit lain." (Informan 12)

5. Pelatihan Teknis Tentang Diabetes Melitus

Petugas penyakit tidak menular pernah mengikuti pelatihan yang di selenggarakan oleh Dinas Kesehatan, namun tidak secara rutin pelatihan tersebut di adakan. Pelatihan ini tidak hanya terfokus pada satu penyakit saja, melainkan pelatihan untuk penyakit yang lainnya juga dan belum semua mendapatkan pelatihan. Berikut kutipan wawancara dengan informan.

"Emm..Pernah sih dulu, pelatihan DM, luka DM." (Informan 12)

"Kita ga setiap tahun ada pelatihan, terus mungkin belum semua terpapar pelatihan diabetes..itu” (Informan 13)

"Biasanya kita banyak belajar sama yang udah pelatihan.” (Informan 14)

\section{Penyediaan Peralatan}

Berdasarkan hasil wawancara dan obervasi ketersediaan peralatan masih kurang memadai karena belum ada alat $\mathrm{HbA} 1 \mathrm{C}$, berikut hasil kutipan

"ngga ada, mesti di rujuk. Kita lab GDS sama GDP aja. Sama 2 jam PP." (Informan 12)

"HbAlC itu kita enga ada yah, itu yang 3 bulan sekali yah, untuk menentukan si penderita itu disiplin atau engga untuk mengendalikan gula darahnya yah heuuh." (Informan 13) "untuk pemeriksaan HbAlc itu saya di rujuk ke lab kimia farma karena disana ga ada ya." (Informan 51)

7. Penyediaan Obat Diabetes Melitus

Berdasarkan hasil observasi dan wawancara mendalam ditemukan bahwa ketersediaan obat diabetes melitus di Puskesmas Bogor Utara sejauh ini sudah mencukupi, kecuali untuk ketersediaan obat insulin.

"Sudah, tidak ada kendala kecuali kebutuhan insulin masih harus lewat ee,,Rumah Sakit.”(Informan 11)

"tidak ada kendala, kecuali pengobatan insulin, insulin juga kita dapatkan rujukan dari Rumah Sakit. Rumah Sakit yang menyediakan" (Informan 13)

8. Pencatatan dan Pelaporan Diabetes Melitus

Berdasarkan hasil wawancara dan telaah dokumen pencatatan masih dilakukan secara manual dan sudah ada formatnya tersendiri sedangkan untuk pelaporan dilakukan seiap bulan dan setiap tahunnya, bentuk laporan dalam bentuk profil Puskesmas. Berikut hasil kutipan wawancara.

"pencatatan si, pencatatan kasus ya..sementara masih manual setau saya, jadi di isi ke format secara manual belum ada yang istilahnya secara online ya untuk ini apa untuk pelaporan diabetes melitus." (Informan 14)

"Formatnya bersatu dengan laporan kasus yang lain, hipertensi, cancer, dan yang lainnya." (Informan 12)

"tadi untuk penyajian datanya, berupa laporan tahunan atau profil kesehatan." (Infoman 14) 
9. Monitoring dan Evaluasi Diabetes Melitus Berdasarkan hasil wawancara dijelaskan bahwa dalam melakukan monitoring dan evalusi hal-hal yang harus di perhatikan adalah target indicator yang sudah di tentukan sebelumnya selain itu juga kepatuhan penderita dalam minum obat, kepatuhan kontrol serta dietnya. Berikut kutipan wawancara.

"Eem yang harus diperhatikan, yaa kepatuhan pasiennya juga, kepatuhan dia kontrol, minum obat, terus eem memperhatikan dietnya, pola hidupnya deh pokoknya. Kalo makan." (Informan 12)

"monitoring dan evaluasi
penanganannya tadi berdasarkan
indikator kinerja dari program PTM
yah karena termasuk program PTM
ya..itu tentunya ada euu..ada target ya,
ada indicator yang harus di perhatikan
ya tapi setiap akhir tahun itu setelah di
ketahui hasil dari capaian kalo belum
memenuhi kan berarti ada..ada..yang
belum tertangani nah ini bagaimana
rencana tindak lanjutnya bagaimana
euu..kemudian intervensinya yang di"
(Informan 14)

\section{3) Output}

Output adalah hasil yang akan di capai sesuai dengan sasaran yang sudah di tentukan. Dalam penelitian ini outpunya adalah untuk mengetahui pencapaian kinerja pengendalian diabetes melitus di Puskesmas Bogor Utara Kota Bogor tahun 2019.

\section{Angka Pencapaian Kinerja}

Berdasarkan hasil wawancara dengan informan proses penentuan pencapaian kinerja adalah dilakukan pada akhir tahun untuk mengetahui hasil capaian kienerjanya dan di satukan dengan penyakit tidak menular lainnya serta angka pencapaian kinerja untuk pengendalian diabetes melitus di Puskesmas Bogor Utara yaitu diperkirakan sekitar $42 \%$. Berikut hasil kutipan wawancara dengan informan.

"yaa,, kita hanya, yang, dia yang berobat ke kita yang tau. Dia yang berobat ke kita dalam satu tahun itu eee dibuat laporan yang dimasukan ke profil. (jeda) persen atau jumlah? Yaa Cuma 3,08\% dari pengunjung puskesmas, eee yang usia 15 tahun ke atas pengunjung puskesmas, dari jumlah 50.000 sekian di tahun 2018, penderita DM 207 jadi 3,08 \% dari 3 kelurahan. Emm kalo untuk itu yah euu..angka pencapaian kinerjanya itu..jadi yang udah di periksa secara menyeluruh atau sesuai standar itu yah paling $42 \%$ dari jumlah penderita jadi berapa tu?emm..itung sendiri yah pokoknya segitu.” (Informan 12)

"nah kalo berapa saya kurang hafal nih, harus diliat, mungkin yang hafal programmernya nanti bisa ditanya ke bu maya yah." (Informan 14).

"Kita disatukan sama penyakit tidak menular yang lain.” (Informan 12)

"perhitungannya yah ada..ada cuma tadi di evaluasi ketika akhir tahun." (Informan 14) 


\section{Pembahasan}

\section{INPUT}

\section{Sumber Daya Manusia}

Tenaga pelaksana pengendalian diabetes melitus di Puskesmas Bogor Utara berdasarkan hasil wawancara dan observasi berjumlah 2 orang yaitu kordinator penyakit tidak menular dan dokter penanggung jawab mengenai penyakit tidak menular. Sedangkan berdasarkan Keputusan Menteri Kesehatan Republik Indonesia No 43 tahun 2016 tentang Standar Pelayanan Minimal, disebutkan bahwa kebutuhan tenaga pelaksana pengendalian diabetes melitus di Puskesmas minimal 3 orang. Tenaga dokter 1 orang, tenaga Nutrition/Gizi 1 orang dan tenaga Perawat 1 orang. Sedangkan hasil penelitian menunjukan bahwa tenaga pengendalian diabetes melitus di Puskesmas Bogor Utara belum sesuai dengan standar, dikarenakan belum adanya tenaga Nutrition/Gizi khusus, akibat dari itu penjaringan pengendalian diabetes melitus menjadi belum optimal.

\section{Sarana Prasarana}

Sarana dan prasarana yang digunakan dalam pelaksanaan kegiatan penemuan penderita Dibetes Melitus menurut Permenkes no 43 Tahun 2016 tentang Standar Pelayanan Minimal diperlukan sarana dan prasarana penunjang agar kegiatan pengendalian diabetes melitus bisa berjalan dengan baik. Berdasarkan hasil dari wawancara dan observasi bahwa sarana yang sudah ada sesuai Permenkes yaitu ruang konsultasi penyakit tidak menular ruang laboratorium yang dipergunakan untuk melakukan pengambilan sampel darah yang kemudian dilakukan pengujian sampai hasil. Menurut Siagian (1996) sarana merupakan komponen input yang memberikan pengaruh suatu kegiatan dapat berjalan dengan lancar atau tidak. Agar roda organisasi dapat berjalan dengan lancar maka persyaratan minimal ketersediaan sarana prasarana tetap harus terpenuhi.

\section{Pembiayaan}

Menurut Undang - Undang Kesehatan Nomor 36 Tahun 2009 menyebutkan bahwa pembiayaan Kesehatan bertujuan untuk penyedinaan pembiayaan kesehatan yang berkesinambungan dengan jumlah yang mencukupi, teralokasi secara adil, dan termanfaatkan. Sumber pembiayaan yang di dapat oleh Puskesmas Bogor Utara untuk pengendalian diabetes melitus yaitu bersumber dari dana Bantuan Oprasional Kesehatan (BOK) dan dari Badan Penyelenggara Jaminan Sosial (BPJS). Anggaran tersebut tidak hanya digunakan untuk kebutuhan pengendalian diabetes melitus saja akan tetapi digunakan juga untuk semua kebutuhan yang ada di Puskesmas Bogor Utara.

\section{Kebijakan}

Menurut Tedjakusnadi (2002), berpendapat bahwa jika kebijakan adalah niat, maka prosedur adalah tata cara untuk melihat prosedur yang ada. Fungsi utama dari prosedur adalah menyiakan predeterminan course of action atau dengan kata lain, sebuah solusi pada masalah yang membutuhkan keputusan yang terus - menerus. Prosedur yang dimaksud adalah cara yang dipakai dalam proses pengendalian diabetes melitus sebagai pedoman atas dasar pelaksanaan kegiatan pengendalian diabetes melitus. Puskesmas Bogor Utara berpedoman pada Surveilans Epidemiologi Diabetes Melitus Departemen Kesehatan tahun 2007 disitu dijelaskan mengenai pendataan sampai dengan monitoring evaluasi mengenai penemuan dan tatalaksana pengendalian diabetes melitus. Selain itu pedoman yang digunakan oleh Puskesmas Bogor Utara 
mengacu pada Instruksi Presiden no 1 tahun 2017 mengenai Gerakan Masyarakat Hidup Sehat (GERMAS) yang di dalamnya berisikan mengenai peningkatan aktivitas fisik dan program yang diberikan Puskesmas Bogor Utara adalah melalui senam prolanis. Landasan hukun selanjutnya adalah Permenkes no 43 tahun 2016 tentang Standar Pelayanan Minimal yang dimana di permenkes tersebut berisikan mengenai tahapan atau pelaksanaan yang harus diberikan Puskesmas kepada penderita diabetes melitus.

\section{PROSES}

\section{Pendataan Penderita DM}

Berdasarkan hasil wawancara dan observasi pendataan yang dilakukan oleh Puskesmas Bogor Utara sudah sesuai dengan buku pedoman surveilans epidemiologi diabetes melitus tahun 2007 dimana dalam buku tersebut di jelaskan mengenai pengumpulan data adalah kegiatan pengumpulan data dengan menggunakan formulir, kuesioner dan check -list serta alat pendukung lainnya (seperti DM Kit). Sedangkan pendataan penderita diabetes melitus yang ada di Puskesmas Bogor Utara yaitu melalui tahapan anamnesa, pengadaan formulir, daftar chek list dan alat pendukung lainnyadiabetes melitus. Serta memberikan informasi kepada penderita mengenai tahapan yang harus penderita diabetes melitus lakukan.

\section{Skrinning Faktor Risiko DM}

Menurut buku Pedoman Surveilans Epidemiologi Diabetes Melitus (2007) skrinning faktor risiko diabetes melitus adalah suatu kegiatan/aktivitas, zat/bahan, kondisi dan factor pencetus yang berkontribusi atau mempunyai pengaruh terhadap terjadinya penyakit diabetes melitus. Proses skrinning yamg dilakukan oleh Puskesmas Bogor Utara sudah sesuai dengan buku pedoman surveilans epidemiologi diabetes melitus. Skrining awal yang dilakukan yaitu di BP umum atau posbindu kemudian di anamnesa dan dilakukan pemeriksaan seperti dilihat dari kondisi dan factor penyebabnya seperti dilihat dari Indeks Masa Tubuh (IMT) yang meliputi tinggi badan, berat badan, lingkar perut serta gejala -gejala klinis yang bermunculan contohnya sering buang air kecil pada malam hari, mudah mengantuk, malas beraktifitas.

\section{Edukasi}

Edukasi yang diberikan Puskesmas Bogor Utara sudah sesuai dengan buku Pedoman Surveilans Epidemiologi Diabetes Melitus (2007). Dimana dalam buku ini dijelaskan bahwa edukasi adalah kegiatan Pendidikan yang dilakukan dengan materi atau pemahaman diantaranya adalah pengertian diabetes melitus, penatalaksanaan diabetes melitus, perencanaan makanan/diet, bentuk aktivitas fisik serta pemahaman mengeni komplikasi diabetes melitus. Puskesmas Bogor Utara rutin melakukan edukasi kepada para penderita penyakit tidak menular khususnya penderita diabetes melitus mengenai upaya pencegahan diabetes melitus, pengendalian diabetes melitus, diet makanan, terapi farmakologi berupa pemberian obat diabetes melitus serta membuat program aktivitas fisik berupa senam prolanis. Hambatan dalam edukasi ini adalah dokter penyakit tidak menular tidak selalu membahas edukasi mengenai penyakit khusus diabetes melitus akan tetapi lebih kepada semua penyakit tidak menular lainnya jadi masih edukasi secara general dan setiap minggu pembahasan dan materinya berbeda -beda.

\section{Rujukan ke FKRTL}

Berdasarkan buku Pedoman Surveilans Epidemiologi Diabetes Melitus (2007) sistem rujukan yang diuraikan disini adalah rujukan medik yang menyangkut khusus pasien 
diabetes melitus dalam wilayah kerja Puskesmas, rujukan medik Rumah Sakit meliputi konsultasi pasien untuk keperluan diagnostik dan pengobatan (termasuk penggunaan insulin). Rujukan ke FKRTL di Puskesmas Bogor Utara yaitu sudah sesuai dengan buku pedoman dan rujukan ini diperuntukan bagi penderita diabetes melitus yang membutukan terapi berupa suntik insulin dan terindikasi ada komplikasi penyakit lain sehingga membutuhkan penanganan yang lebih lanjut.

\section{Pelatihan Teknis Tentang}

Diabetes Melitus Berdasarkan Permenkes 43 tahun 2016 mengenai Standar Pelayanan Minimal Pelatihan teknis pelayanan kesehatan tentang DM bagi tenaga kesehatan, termasuk pelatihan surveilans DM berbasis web. Sedangkan hasil wawancara mengenai pelatihan teknis tentang Diabetes Melitus di Puskesmas Bogor Utara sebagian petugas sudah mendapatkan pelatihan yang diselenggarakan oleh Dinas Kesehatan Kab/Kota setiap tahunnya. Namun setiap tahun tidak selalu pelatihan mengenai diabetes melitus saja yang petugas dapatkan tetapi pelatihan penyakit lain juga, selain itu tidak semua petugas mendapatkan pelatihan.

\section{Peralatan Diabetes Melitus}

Berdasarkan Permenkes No 43 tahun 2016 mengenai Standar Pelayanan Minimal Pengendalian Diabetes Melitus (DM) peralatan yang digunakan Reagen Pemeriksaan kesehatan DM, Pengadaan Glucometer tes dan Spektofotometer termasuk alat HbA1C. Hasil wawancara dan observasi di Puskesmas Bogor Utara peralatan yang ada di Puskesmas sudah sesuai dengan Permenkes dan terdistribusi dengan baik. akan tetapi alat untuk pemeriksaan $\mathrm{HbA} 1 \mathrm{C}$ di Puskesmas Bogor Utara belum tersedia hal ini disebabkan karena alat tersebut harganya mahal.

\section{Obat Diabetes Melitus}

Menurut Peraturan Menteri Kesehatan Republik Indonesia Nomor 74 Tahun 2016 tentang standar Pelayanan Kefarmasian di Puskesmas. Obat adalah bahan atau paduan bahan, termasuk produk biologi yang digunakan untuk mempengaruhi atau menyelidiki sistem fisiologi atau keadaan patologi dalam rangka penetapan diagnosis, pencegahan, penyembuhan, pemulihan, peningkatan kesehatan untuk manusia. Ketersedian obat Diabetes Melitus (DM) di Puskesmas Bogor Utara sudah cukup karena untuk ketersediaan obat di Puskesmas sudah dilakukan perencanaan dengan baik sehingga stok obat diabetes melitus di Puskesmas Bogor Utara tidak pernah kekurangan. Obat yang tersedia di Puskesmas Bogor Utara yaitu berupa obat oral dengan jenis obat yaitu Metformin dan Glibenclamid. Hambatan atau ketidaksesuaian terkait obat adalah tidak tersedianya obat insulin

sehingga bagi penderita yang membutuhkan terapi insulin harus dirujuk ke FKRTL yang lebih lengkap.

\section{Pencatatan dan Pelaporan}

Diabetes Melitus Hasil wawancara dan observasi mengenai pencatatan dan pelaporan di Puskesmas Bogor Utara sudah sesuai dengan Permenkes No 43 tahun 2016 mengenai Standar Pelayanan Minimal Pengendalian Diabetes Melitus (DM). di dalam peraturan ini dijelaskan bahwa Pencatatan dan Pelaporan Diabetes Melitus meliputi data jumlah penderita dan data jumlah penderita yang sudah di tangani disertai dengan Formulir pendataan. Pelaporan diabetes melitus harus di laporkan setiap bulan dan tahun ke Dinas Kesehatan setempat. Pencatatan dan pelaporan di Puskesmas Bogor Utara di lakukan setiap hari 
dan kemudian dibuat dalam bentuk laporan bulanan yang kemudian di laporkan ke Dinas Kesehatan sebelum tanggal 10. Selain itu juga ada laporan dalam bentuk laporan tahunan, dimana laporan tersebut di dapatkan dari laporan setiap bulannya. Hasil dari laporan tersebut akan dilakukan monitoring dan evalusi oleh pihak Puskesmas bersama.

\section{Monitoring dan Evaluasi}

Menurut Casey \& Kumar (1987). Monitoring dan Evalusi adalah penilaian secara terus menerus terhadap fungsi kegiatan baik dalam jadwal pelaksanaan maupun input dan sasaran kegiatan. Menurut hasil wawancara dengan petugas monitoring di Puskesmas Bogor Utara dilakukan secara terus menerus dan dilihat dari hasil penjaringan kasus Diabetes Melitus (DM) dengan cara melakukan pemeriksaan secara berkala kepada penderita dan yang beresiko. Monitoring merupakan bagian penting yang integral dalam managemen sehari-hari. Setelah di monitoring dilakukan evaluasi mengenai sejauh mana

\section{Kesimpulan}

Berdasarkan hasil penelitian yang sudah dijelaskan pada bab sebelumnya maka peneliti menyampaikan beberapa hal yang merupakan gambaran singkat mengenai hasil penelitian yang telah dilaksanakan, berikut kesimpulan nya.

1. Komponen Input yaitu (Pembiayaan, Sarana dan Prasarana, Kebijakan dan SDM). Dari ke empat komponen ini yang belum sesuai dengan Permenkes 43 tahyn 2016 adalah SDM, jumlah SDM yang masih kurang mengakibatkan proses pengendalian menjadi terhambat.

2. Komponen Proses yaitu (Pendataan penderita DM, Skrinning Faktor Risiko DM, Edukasi, Rujukan, Pelatihan, Peralatan, Obat, Pencatatan dan Pelaporan serta Monitoring dan Evaluasi) dari ke tingkat keberhasilan yang sudah dilakukan oleh petugas apabila belum optimal maka akan dilakukan tindak lanjutnya harus seperti apa. Kegiatan Monitoring dan Evaluasi ini sudah sesuai dengan buku Pedoman Pengendalian Diabetes Melitus.

\section{OUTPUT}

1. Angka Pencapaian Kinerja

Berdasarkan Permenkes No 43 tahun 2016 mengenai Standar Pelayanan Minimal Pengendalian Diabetes Melitus (DM). Capaian kinerja Pemerintah Kabupaten/ Kota dalam memberikan pelayanan kesehatan sesuai standar bagi penyandang DM dinilai dari persentase penyandang DM yang mendapatkan pelayanan sesuai standar di wilayah kerjanya dalam kurun waktu satu tahun. Berdasarkan hasil wawancara dengan Puskesmas Bogor Utara angka pencapaian kinerja pengendalian Diabetes Melitus di Puskesmas Bogor Utara di perkirakan sekitar $42 \%$ hal ini disebabkan karena proses pelaksanaan belum dilakukan secara optimal.

Sembilan komponen yang belum optimal terdapat pada komponen edukasi yaitu karena edukasi yang diberikan masih secara general, komponen pelatihan belum dilakukan secara rutin dan secara khusus, komponen peralatan yaitu belum tersedianya alat $\mathrm{HbA} 1 \mathrm{C}$ dan kompenen obat yaitu belum tersedinya obat terapi insulin bagi penderita DM.

3. Komponen Output pada pengendalian diabetes melitus yaitu angka pencapaian kinerja di Puskesmas Bogor Utara saat ini belum optimal hal ini disebabkan karena keterbatasan petugas, keterbatasan tenaga terlatih dan keterbatasan alat $\mathrm{HbA1C}$ dan keterbatasan obat Insulin. Menurut Puskesmas Bogor Utara saat ini angka pencapaian kinerjanya sekitar $42 \%$. 


\section{Daftar Pustaka}

[1] Afifah Lily Adita. (2015). evaluasi input program pengendalian DM di Dinkes Kabupaten Magelang. Magelang. Diakses pada tanggal 27 februari 2019

[2] American Diabetes Association. (2011). Standards of Medical Care for Patients with Diabetes Melitus, Diabetes Care 25, di akses pada tanggal 30 januari 2019

[3] Azwar. Azrul. (2010). Pengantar Administrasi Kesehatan Jakarta: Bina Rupa Aksara Publis

[4] Bustan, M.N. (2007). Epidemiologi Penyakit Tidak Menular, Cetakan Kedua, Edisi Revisi, Jakarta: Penerbit Rineka Cipta.

[5] Center for Disease Control and Prevention (CDC). (2011). Introduction Program Evaluation for Public Health Programs: A Self-study Guide. Atlanta: Center for Disease Control and Prevention

[6] Departemen Kesehatan Republik Indonesia. (2008). Pedoman PengendalianDiabetes Melitus. Di akses pada 30 Januari 2019

[7] Ernawati., 2013. Penatalaksanaan Keperawatan Diabetes Melitus Terpadu, Jakarta: Mitra Wacana: Mitra Wacana Media

[8] International Diabetes Federation (IDF). (2013). IDF Clinical Guidelins Task Force. Global guideline for Type 2 diabetes, di akses pada tanggal 30 Januari 2019

[9] Notoatmodjo, Soekidjo., 2015. Metodelogi Penelitian Kesehatan Jakarta: Rineka Cipta
[10] Novo, Nordisk, (2013). Prevalensi Diabetes Melitus Di Aceh 8,7 Persen, Jakarta: Gramedia Pustaka Utama.

[11] Pedoman DM. (2007). Pedoman Surveilans Epidemiologi Diabetes Insulin. Menurut Puskesmas Bogor Utara saat ini angka pencapaian kinerjanya sekitar 42\%. Melitus Departemen Kesehatan tahun 2007

[12] Perkeni. (2015). Konsensus Pengelolaan Diabetes Melitus di Indonesia, Jakarta.

[13] Permenkes RI. (2016). Peraturan Menteri Kesehatan Republik Indonesia No 43 tahun 2016 tentang Standar Pelayanan Minimal Bidang Kesehatan.

[14] Permenkes RI. (2016). Tentang Peraturan Menteri Kesehatan Republik Indonesia Nomor 74 Tahun 2016 tentang standar Pelayanan Kefarmasian di Puskesmas.

[15] Permenkes RI. (2014). Peraturan Menteri Kesehatan RI Nomor 75 tahun 2014 Tentang Puskesmas, Jakarta: Permenkes RI. Perpres RI. (2017). tentang Instruksi Presiden no 1 tahun 2017 mengenai Gerakan Masyarakat Hidup Sehat (GERMAS)

[16] Riskesdas. (2013). Pusat Data dan Informasi Kementrian Kesehatan Republik Indonesia. Di akses pada tanggal 30 Januari 2019.

[17] Sondang P, Siagian.1996. Manajemen Sumber Daya Manusia. Jakarta: Bumi Aksara

[18] Tedjakusnadi,ari.(2010). Manajemen Administrasi Kesehatan. Jakarta: Bumi Aksara

[19] UU RI. Tahun (2009). Undang-Undang Kesehatan Nomor 36 Tahun 2009 
[20] UPTD Puskesmas Bogor Utara. (2018). Profil Puskesmas Bogor Utara Kota Bogor Tahun 2017. UPTD Puskesmas Bogor Utara

[21] WHO (2016). Monitoring Health for The SDGs Sustainable Development Goals. Di akses pada tanggal 30 Januari 2019. 